\title{
The Commons: Three Case Studies of Community Forested Land
}

\author{
Ruth B. McKay, Ph.D. \\ Sprott School of Business, 914 Dunton Tower, Carleton University, \\ 1125 Colonel By Drive, Ottawa, Ontario, K1S 5B6, Canada \\ Tel: 613-520-2600 Ext.6013. E-mail: ruth.mckay@carleton.ca
}

Received: November 11, 2015 Accepted: December 30, 2015 Published: April 15, 2016

doi:10.5296/jpmr.v2i1.8562ＵRL: http://dx.doi.org/10.5296/jpmr.v2i1.8562

\begin{abstract}
This paper examines three communities that include common land in the community design. The common land provides natural habitat for recreational purposes along with privacy and a natural visual barrier. One of the three communities the commons arrangement fails after more than thirty years and the community sells most of the common land for private ownership. The other two are examples of successful commons where the community maintains the common lands and exhibits a growing commitment to the holding of common land. The paper examines why two of the three communities have success and prosper while the third fails. The findings provide insight into designs that work to maintain community common land and those that fail.
\end{abstract}

Keywords: Commons, private land, public land, governance, conflict, cooperation

\section{Introduction}

In North America privately held common lands (held outside government lands) are less popular than individual owned private lands. From an economist's perspective as land becomes scarce private property rights, through the establishing of private property, is more efficient in the use and care of the land resource than that of common lands. The scarcity of land that drives private land holdings is associated with the population accessing the resource. "When population pressure on the resource intensifies growing competition causes an increasing incident of externalities ${ }^{1}$ among users” (Baland \& Platteau, 1998, p. 644).

\footnotetext{
${ }^{1}$ Externality in this discussion refers to a side effect or consequence of the activity of the users of the common land.
} 
As the number of users of the common lands increases the quality of the common lands can be negatively impacted through overuse and competing interpretations of what is an acceptable use of the land (Ostrom, 1990). For example, in the three cases examined in this paper the resource in the common lands is recreational and natural forested areas. The lands are treed and have walking trails through the treed areas. While most people in the communities recognize the use of the common land is for non-motorized vehicles some residents push for access by ATVs and dirt bikes. Another consequence of the number of users of the common land is the cutting of trees by abutting landowners who have ownership in the common lands. According to Baland and Platteau, (1998), in order to limit the externalities and reduce efficiency losses and resource depletion of common lands a community either increases regulations or accepts the division of property and private property ownership splitting up the common lands. With a small number of users the regulations and monitoring of the common lands is easy given the familiarity among participants but as the numbers increases this oversight becomes more difficult making private property an attractive alternative.

At the same time there is a limit to the benefits of private property. If an individual or family wants to own a home and land for recreation the cost may be more than the individual or family can afford. To fully benefit in a society that favours private property over common lands, an individual has to have enough financial resources to afford the amount of land they need to meet their desired uses or reside near large tracks of accessible common or private lands. In many cases this results in urban dwellers traveling outside the city on weekends as weekend warriors, to access nature of a reasonable size and ruggedness as most cannot afford land sufficient for their recreational purposes in their place of work and residence. People travel to cottages, parks, ski, bike or golf resorts in order to access natural spaces for recreational purposes. The travel can be time consuming and detrimental to the environment. Entrance fees for using public or private lands can also be expensive.

In Canada, this means that property near pubic land, such as parks owned by municipalities, provinces or federally, or land with waterfront will include a price premium to reflect the benefits the natural space provides to nearby owners. However, according to Farley et al. (2015, p. 72), "Current trends suggest that neither markets nor government are adequate for achieving the sustainable, just and efficient use of resources. A promising institution designed to address this problem is the common assets trust.... legal relationship between trustees, who manage a pool of wealth, and beneficiaries, for whom the wealth is managed." The common lands maintained as a trust or maintained by adjoining landowners can provide the asset advantage of the common lands while defraying the cost and responsibilities of maintaining the lands. However, underlying this advantage of common lands is the challenge of how to structure the managing of the common lands in order to reap the greatest benefit and avoid the management structure failing due to factors like cost, imbalance of benefits, conflict or externalities.

"Many societies demand property rights to land and natural resources for sustainable resource management, secure livelihoods, and cultural identity. Yet policy makers struggle in legislating and implementing effective property regimes” (Coleman \& Mwangi, 2015, p. 855). 
Coleman and Mwangi (2015) argue the answer to properly managing common lands lies in rational choice theories of conflict (competition) and cooperation. The perspective of the users of the commons, cooperative or competitive, impacts the type of common property institution that is formed and the subsequent distribution of benefits. According to conflict theory, those in positions of power disproportionately benefit from the common property. In the sphere of cooperation theory both those in positions of power and those of lesser power will benefit from the commons.

This paper will examine three cases of communities designed around common property. All three began over 30 years ago. Two communities have been very successful, but one failed. The two that have prospered were structured based on the advantage of the common lands while for the third community the common land was not central to those who designed the community. However, in all three cases the common lands were critical to the enjoyment of those who bought into the communities. In the case of the failed design, the common lands were owned by more people, over 200 individuals and families, than were in the two surviving communities that both had less than 30 individuals and families.

This paper will start with a brief review of the concept of common lands. Next the description of each of the three communities that included common lands will be provided. These are identified as case one, two and three. The names and details for some of the cases have been disguised for confidentiality purposes however the country for the cases is Canada. Finally, the differences of the three designs will be examined and how these designs led to different outcomes - success versus failed designs.

\section{The Commons}

A common is a shared resource such as land, water, oil or air. Until the concept of private property was introduced all lands and resources were common. Some resources, such as the air we breathe and fish in the oceans, remain as common resources. "Rivalry in consumption and difficulty of exclusion make provision and protection of common-pool resources particularly challenging” (Poteete \& Ostrom, 2004, p. 435). Research on the commons has concluded with particular design features that have led to greater success in the preserving and sharing of the resource. In her book, "Governing the Commons: The Evolution of Institutions for Collective Action,” Ostrom (1990, p. 1) argued that community resource governance in the form of a commons demonstrated "reasonable degrees of success over long periods of time." She pointed out that in contrast "neither the state nor the market is uniformly successful in enabling individuals to sustain long-term, productive use of natural resource systems.” Ostrom (1990, p. 90) specified eight factors that were essential to the long term success of the common property. These eight factors were: clear resource boundaries; clear rules of membership within the commons; congruence between rules of the commons and local regional conditions; arenas for 'collective choice'; mutual monitoring of the commons; 'graduated' sanctions for those breaking the rules of the commons; mechanisms for conflict resolution within the commons; and local rights of organization giving the commons the right to be a legal entity. 
Ostrom argued that individuals that were "well informed and with minimum rights of autonomy and monitoring - could undertake collective action to protect communal resources without causing irreparable degradation” (Forsyth \& Johnson, 2014, p. 1106). An alternative perspective of commons was presented by Hardin in his publication entitled The Tragedy of the Commons ${ }^{2}$ (1968). Hardin raised concern about the overuse or overgrazing of common or public resources. The more one individual benefits by extracting benefits from the common lands, such as the more animals an owner grazes on the common lands or fish they remove from common waters or land, the more they benefit and the less there is of the resource for others to access. The commons also can lead to a free-ride effect where some members contribute little or nothing in terms of resources to maintain or pay of the common resource while other members provide more than their share (Grossman, Pirozzi, \& Pope, 1993). Hardin (1968) created a negative perception of the commons by pointing out that individual greed could overuse and destroy common resources. Thus government ownership or private ownership offered greater security for the resources.

Ostrom's work offers a more positive approach than found in Hardin's work (Forsyth \& Johnson, 2014). The focus should be more on what is needed to make a common successful rather than tossing the approach of the commons out entirely. For example, Dagan and Heller (2001, p. 16) asserted that elements of both private and commons property joint ownership arrangements can have substantial benefits over individual ownership. Thus a commons could include some private ownership or similar arrangement to make the commons successful. A community is then committed to the success of the common land based on their abutting private land ownership.

Poteete and Ostrom (2004) examined the link between group size and success of the commons. They point out that past a core number of participants there are reasons why the more participants the less successful the common. In smaller groups there is more interaction and mutual monitoring, increased value of reputation for cooperative behaviour and overall more trust. However the larger the group the less face-to-face interactions and the higher the transaction costs because interactions eventually require a third party to complete such as the hiring of someone to oversee the communications and transactions among members. Heterogeneity was also examined by Poteete and Ostrom but seems to be less of an issue than group size. Poteete and Ostrom (2004) conclude that a large group is not necessarily ineffective in running a commons. "A single optimal design of institutional rules does not exist ... (Groups need) "to pay more attention to the diversity of institutional arrangements that can be used to overcome collective-action problems” (454). This means that a common with a large number of commons owners is still viable but the owners need to be aware of the potential problems the number of owners could create and how to overcome these limitations without unmanageable expenses.

Ostrom (1990) identified eight factors linked to the success of caring and maintaining common resources. Are these sufficient to determine success versus failure or are there other

\footnotetext{
2 The tragedy of the commons refers to instances where individuals acting in their self-interest act contrary to the interests of the whole or common exhausting or degrading a common resource.
} 
factors that impact the longevity of a commons community? The following section will outline three cases of commons communities. The first two cases include a combination of commons land and private land while the last one is solely common lands but has specific land assigned to common's members. These cases will be followed by examining causes of the success and failure of these commons.

\section{Three Case Studies}

\subsection{Case One: Sugarbush}

The Sugarbush subdivision was originally built in 1974 and 1975 by two developers, Kitwee and Modco, in two initial phases. Sugarbush was created as a seasonal ski community, located near a ski resort, with unique wood chalet style homes nestled in the mature maple and beech forest in a rural area that had no municipal services (North Simcoe Community News, 2009).Phase one consists of 94 building lots, Phase two of 63 building lots. Eventually, in 1988, a third phase of development was added.

"Under the initial development agreement with the local municipality, Kitwee and Modco provided the part-time residents of Sugarbush with a number of services that the municipality was unable or willing to provide, including snow and garbage removal and the supply of clean water." (Caselaw, 1999) Kitwee and Modco tried to turn the first two phases of the subdivision into a condominium in order to allocate the service costs to the residents. The municipality rejected the application. Instead the developers created a corporation run by an association, named the Indian Park Association (IPA), to govern the management of the land in the two phases." The association undertook to manage and maintain for the residents the water supply and distribution system. Kitwee also transferred some land in Sugarbush to the association to be used for a common parking lot and a recreational centre” (Caselaw, 1999). As part of the community, the residents were subject to a number of restrictive covenants. These included not being able to build individual driveways, fences, or garages. Trees could only be removed if dead or diseased. Also, some changes to a home, such as alternations or improvements, required written approval from the association.

In addition to the services for the residents of phase one and two, the association maintained the ownership of certain lands as the common lands of Sugarbush. These lands ran between and around some of the residential lots and provided walking paths through the forested areas in the community and to the community centre. The association took on the responsibility to manage, maintain and improve such lands for the benefit of the members of the association. The association hired an individual to oversee the work to run the services and maintain the common land and recreational facility. The association became responsible for erecting and maintaining a recreation centre from the land transferred from the developer. It was also responsible to promote social activities among the members and to assess and collect from the members yearly payment to maintain the services and common properties. The association was managed by seven residents who were elected to the association board of directors. There were two levels of the association memberships - voting and non-voting. Both memberships cost $\$ 600$ per year. The voting members signed a contract to remain members for as long as they owned their home in Sugarbush. They also had an equity interest 
in the association. The non-voting members could not serve on the board and had no equity interest. They were not required to sign an agreement that they would remain members for as long as they had a home in the community.

Once built, the association ran the recreational centre. It provided a pool table, outdoor play area, Ping-Pong table, sauna, exercise room, kitchen, administrative offices for the association and an outdoor pool. Any member could book the building for an event for a nominal fee (Indian Park Association, 2006).

In 1988, the board of directors of the association negotiated with a developer Monica Interior Designs Ltd., the owner of adjoining land, to amalgamate its land with the Sugarbush properties and build a third phase of the development, However, instead of adding to the existing seasonal cottage community, Monica developed its land into a modern residential subdivision, consisting of year round homes with amenities including individual driveways, garages and basements. Phase three consisted of 178 lots on which Monica built 82 permanent homes (Caselaw, 1999).

In 1999, the residents in phase three launched a legal case against the association arguing that the restrictive covenants were too onerous and as a result many of them were not paying their association fees. IPA countered the legal case with their own legal case based on the members not paying their annual fees. Around the same time the municipality took over the responsibility of garbage pick-up, plowing the roads and overseeing the water supply and added service delivery costs to resident's tax bills. The reason for this change was in part the arrival of near-by communities where the municipality assumed the delivery of services.

In 2012, the members of Sugarbush voted to close the IPA because too many of the people in the subdivision were not paying their fees and the legal cost of enforcing the yearly fee was too much to pay. Areas where the common land was appropriately situated near a road and the land was reasonable for building were sold off as building lots. The rest of the land approximately 80 acres - was kept as common lands and the recreational facility was sold to be renovated into a home. The association then offered the common lands to the Township of Oro-Medonte but the township was not interested. They also tried to donate the lands to the County of Simcoe.

\subsection{Case Two: Maplegrove}

Maplegrove is a street that has 28 residential property lots. The lots sit on a hill and are surrounded by 52 acres of common land that provides both a visual and natural barrier. The community was designed in 1985 by Peter Fairbank as a retirement community that situated a street of homes in nature. The community is situated near a downhill and cross country ski resort. In 1988 the first home in the community was built by Fairbank. Fairbank built a total of six homes on the street. The rest of the 22 building lots were bought by families. In total an additional 21 homes were built on the street (MGA, 2014).

The lots in the community include restrictive covenants. For example, the home size of being no less than 2000 square feet and there is no outside storage of boats, snowmobiles, recreational vehicles, or ATVs. The common property in the community includes an indoor 
and outdoor storage facility for large vehicles and wood. The covenants aim to maintain a standard of appearance for the community (MGA, 2014).

The community common lands are overseen by the Maplegrove Association (MGA). The association is run by volunteers. It is run based on input and funding by the residents. Decisions made by the association are not legally enforceable. All residents are members of the association as long as they pay an annual fee. The membership payment entitles the residential lot owners to one vote in the MGA. The association deals with the maintenance and preservation of the common land. This includes the maintenance of grounds at the entrance to the community, private property signs and fencing at entrances to the common land. The MGA also ensures insurance of the common lands are in effect. Two meetings are held a year by the association to consider any issues or ideas related to the common land. The association has five officers that are elected for two-year terms (MGA, 2014) to deal with property and maintenance concerns and social events.

In a 2015 document the MGA clarified the vision of the common lands in terms of the responsibility of the association. The MGA "commits to the preservation, environmental protection, and natural enhancement of the common lands through all-seasons responsible stewardship. ...(I)nvestment, management and use of the common lands are guided by a desire to protect and enhance:

- the natural environment

- property values

- recreational and social opportunities

- the safety of residents

- privacy and discouragement of incursion

- a natural or defined buffer at the perimeters

- $\quad$ wildlife and plant life” (MGA, 2015)

The community is supportive and helpful to its members. All but one resident is a member of the association and pays their annual MGA fees which run around \$300 per year. The paying members view the non-paying member as a possible free rider but are willing to give the member multiple opportunities to pay their fees and prove otherwise. The community is situated in a rural setting. All properties have the natural wooded land of the commons in back of their property. The long-term value of the common lands is to ensure privacy, maintain land values and provide recreation.

\subsection{Case Three: Pine Tree Way}

Pine Tree Way is a community based on common land ownership of 325 acres. The community does not include individual private property. The land was purchased in 1966. In 1967 an access road was added branching from the closest public road traveling north and south of Pine Tree Lake. Pine Tree Way differs from typical cottage and recreational property as the members of the trust abide by rules that prevent individuals from drastically affecting 
the land. "Excessive removal of tress, or construction projects, must first be approved by the trustees with the goal of minimal ecosystem impact as a priority" (Pine Tree Way, 2015, p. 3). In addition, "Strict guidelines are in place to ensure member cottages and recreation respect the property and the privacy of others" (Pine Tree Way, 2015, p. 6).

Individuals or families who are part of the community are assigned to a portion, designated in 150 foot lots, of the common property. The property includes Pine Tree Lake, a small lake that the community designated as motorboat free. The property was purchased by 28 individuals and families set up as a trust. The group set up lots on the east side of the lake. The initial owners put their 28 name in a hat and pulled the numbers to establish a selection order for the lots. The lots remained part of the common lands but individuals/families are assigned to the specific lots. Because the lots have stayed as common land, the lots are recognized as a benefit of the membership in the trust, not private property.

Early in the formation of the trust the vision of the community was contested. A subgroup wanted to have the freedom to build any residential structure in any location. They also wanted to extend the road on the south side of the lake - an undertaking which would have been very expensive. The conflict that ensued resulted in the majority of the owners buying out the contesting minority, reducing the number of lots to 20.

Since the inception almost half of the landowners have built a cottage on their properties. Taxes for the common land are based on a division across the landowners based on a set rate for those with land no building (\$300-400 per year) and a higher rate for those with buildings. The property does not have electricity or land line phone service.

In an effort to maintain the vision of the community the community maintains the trees on the common land (not designed as individual lots) through a provincial program called the Managed Forest Tax Incentive Program (MFTIP). The objective of the MFTIP is to maintain healthy forests in order to contribute to a healthy environment - a goal that fits well with the goals of the community.

Pine Tree Lake members vote in seven members to act as executives of the trust in two year positions. Each year two meetings are held in order to discuss any outstanding issues (such as road and forest maintenance) and approve the yearly budget. Initially a community building was maintained on a lot not assigned to any particular individual providing residents with an option for guests to stay or for those without a building but the cost of maintaining the building and the building code standards of the township led to the building and the lot upon which it sat being offered to any of the 20 members as a swap for the lot that they held. This resulted in the communal building and lot being swapped with a landholder without a building removing the community building and associated costs from the trust budget.

The trust continues to be a success with more new members interested than those willing to sell. Much of the interest in the lots comes from friends and family members of those that already have property on the lake. The increasing land values in the region have contributed to a general sense of contentment in the community by the members. 


\section{Case Comparison}

The benefit of the common land, and restrictive covenants that runs with the land, for these communities is similar but not identical. For the Sugarbush community the common land provided walking trails, a natural beauty to the community setting and a property for a recreation centre. With Pine Tree Way the benefits include privacy, the ability to make the lake motorboat free, and control over intrusion on the natural environment. In the final case, Maplegrove, the benefit of common land is privacy, enhanced land value and a natural setting for the community. To evaluate the design and benefits more fully factors relating to the differences in the three communities have been itemized in Table 1. Table 1 summarizes the key points set out in the case summaries clarifying the difference between the three cases.

\section{Success versus Failure}

\subsection{Failed Commons}

The Sugarbush community design failed for a number of reasons. Firstly, the composition of the residents changed over time. The initial design of the Sugarbush community attracted retirees and outdoors people to the community. For some of the residents the homes were second homes that allowed them skiing and other nature and recreational options. But changes in the land usage and residents resulted in challenges to the model and vision of the community. Land values in nearby cities went up relative to the property values in the Sugarbush community. As a result the aging homes in phase one and two of the Sugarbush community attracted more do-it-yourself residents, families that wanted a home with over an acre of land and also lower income residents. These new residents were not attracted to the community for the common land or the vision that was originally created for the community. The introduction of the third phase of the development included residential homes rather than recreational designed homes and homeowners that wanted the freedom to use their property without limits on removing trees and building extensions or undertaking renovations. The homes in the third phase were situated on smaller lots with fewer trees. The home owners in phase three wanted the freedom to use their property as they would have if they had bought anywhere else in the municipality. There was a lack of congruence between the restrictive covenants of the Sugarbush community and the local regional bylaws (Ostrom, 1990).

The adoption of water, garbage pickup and plowing services by the municipality also created resistance to the payment of the annual fees by community members. There was a general feeling that with the costs moved to the individual resident's tax bills the association fees should be significantly reduced. The new mix of residents in phase one and two also resisted the association fees as they had limited interest in the common lands. The association had expenses of maintaining the recreational facility and overseeing the collecting of the fees and maintaining of the common lands. This management was given over to a paid individual rather than volunteers because of the size of the community. The garbage, water and snow removal services were adopted by the municipality for the Maplegrove community as well but this did not result in a backlash by the land owners as the fees were adjusted to reflect the change. 
Another reason for the failure of the Sugarbush community was the size of the commons. With substantially more members there was a greater divergence in interest in the common property and surrounding community. These differences made it more difficult to reach consensus on common's issues. There were also greater transaction costs to run the common than that found in the smaller commons and a greater number of free-riders not paying their membership fees. The free-riders were also not being held immediately accountable because of the lack of face-to-face interactions with fellow members. The free-riders were dealt with through warning letters and then through lawyers delaying resolution and creating a more conflictual relationship between the members and the administrators of the commons.

With the Sugarbush community legal action taken against non-paying members, the high annual cost of the membership fees and bad blood that had developed among some residents over the application of the restrictive covenants resulted in lower property values. The community also developed a reputation for being divisive and having problems. The rational choice approach of competition rather than cooperation prevailed (Coleman \& Mwangi, 2015) taking away from the notion of the common benefit of sharing land.

Finally, the Sugarbush community did not have “"graduated' sanctions for those breaking the rules" of the community or "effective mechanisms for conflict resolution” (Ostrom, 1990, p. 90) within the community. If the annual fees were not paid by a resident the association could and did take legal action. This response differed considerably to the way residents in the Pine Tree Lake community dealt with those that did not pay their fees. With Pine Tree Lake if a resident missed a payment discussion and accommodations were made to help the resident meet the payment.

\subsection{Successful Commons}

The success of the Pine Tree Lake and Maplegrove community were due in large part to the number of residents in the community. Being smaller communities monitoring could be done easily and face-to-face without a heavy application of restrictive covenants. The members also met regularly at their places in the common land to discussed and resolved issues in the community informally. If a problem arises that requires the input of the whole membership the issue is added to the agenda for the next commons meeting. In both these communities the formal commons meetings are held twice a year and all community members are invited and encouraged to attend. Each family or property holds one vote on any decision that is made.

While all three communities held social events the two successful communities had more members in attendance relative to the total membership than the common that failed. In addition, the social events and meetings were often held in a member's home or cottage creating more of a personal connection among the members. In the failed common the get togethers were held at the community centre.

Another reason for the success of Pine Tree Lake and Maplegrove communities was the common land and the community vision did not detract from the land value of the community. When members would describe their community they would describe the common land as 
being an extension of their property or designated land and identify the commons as adding to their enjoyment of their property. In both cases the common land added to the value of the private property or property value as a whole. In the case of Maplegrove if the common land was separated out from the community the individual properties would go down in value.

The members described their communities as being unique and having value that could not be expressed in the dollar value of the land. They used the words "sanctuary" and "retreat" to describe their community. Also, Pine Tree Lake and Maplegrove both had a long list of family members and friends who expressed an interested in joining the communities should properties come up for sale. The word of mouth land transfer ensured that new members were more likely to accept the objectives and values espoused by the commons. This process acted as a prescreening for new members.

Finally, in both cases the common-private land arrangements were unique in the areas the communities resided in and kept the overall cost of the properties and taxes down compared to each property owning individually the equivalent of the common lands. The members recognized this benefit and worked together to make their communities work to keep the commons successful and operational.

\section{Conclusion}

The three communities highlighted in this paper included common land and private land assembled together in a community in two of the cases and in the third only common land with assigned lots that adopted many of the same rights as that of private land. The two communities that survived and prospered consisted of under 30 individuals or families. As a result, and in keeping with the conclusions of Poteete and Ostrom (2004), the monitoring of the community rules and the sharing of the community vision was easier, less expensive and more effective with the smaller community. It also meant that the application of the community rules could be applied in a more flexible manner not requiring the involvement of legal action.

\section{References}

Baland, J. M., \& Platteau, J. P. (1998). Division of the commons: a partial assessment of the new institutional economics of land rights. American Journal of Agricultural Economics, 644-650.

Caselaw. (1999). Berry vs. Indian Park Association 1999 1294. Retrieved from http://caselaw.canada.globe24h.com/0/0/ontario/court-of-appeal-for-ontario/1999/05/03/berry -v-indian-park-association-1999-1294-on-ca.shtml

Coleman, E. A., \& Mwangi, E. (2015). Conflict, Cooperation, and Institutional Change on the Commons. American Journal of Political Science.

Grossman, P. J., Pirozzi, M., \& Pope, J. (1993). An empirical test of free-rider behaviour. Australian economic papers, 32(60), 152-160.

Dagan, H., \& Heller, M. A. (2001). The Liberal Commons. 110 YALE L.J. 549, 581-87 
Hardin, G. (1968). The tragedy of the commons. Science, 162(3859), 1243-1248.

Farley, J., Costanza, R., Flomenhoft, G., \& Kirk, D. (2015). The Vermont Common Assets Trust: An institution for sustainable, just and efficient resource allocation. Ecological Economics, 109, 71-79.

Forsyth, T., \& Johnson, C. (2014). Elinor Ostrom's Legacy: Governing the Commons and the Rational Choice Controversy. Development and Change, 45(5), 1093-1110.

Indian Park Association. (2006). Sugarbush. Retrieved from http://denada99.tripod.com/contact.html

North Simcoe Community News. (2009). Sugarbush Scuttlebutt. Retrieved from http://www.northsimcoenews.com/index.php/online-edition/18-octobernovember-thanksgivin g-issue/105-sugarbush-scuttlebutt

Maplegrove Association (MGA). (2015). Common Lands Committee Report for the Oro Hills Property Owners Association: Vision, Recommendations and Guidelines Nov 1, 2015.

Maplegrove Association (MGA). (2014). Welcome Package.

Ostrom, E. (1990). Governing the commons: The evolution of institutions for collective action. Cambridge University Press.

Poteete, A. R., \& Ostrom, E. (2004). Heterogeneity, Group Size and Collective Action: The Role of Institutions in Forest Management. Development and Change, 35(3), 435-462.

Pine Tree Way. (2015). Stewardship Plan: For the woodlands owned by the Pine Tree Way, 2015-2034.

Table 1. Differences in the Communities

\begin{tabular}{|c|c|c|c|}
\hline $\begin{array}{l}\text { Features of the } \\
\text { Communities }\end{array}$ & Sugarbush & Pine Tree Way & Maplegrove \\
\hline Purpose of ownership & $\begin{array}{c}\text { Recreational that } \\
\text { changed to residential }\end{array}$ & Recreational & Residential \\
\hline $\begin{array}{l}\text { Purpose of Common } \\
\text { Land }\end{array}$ & $\begin{array}{c}\text { Recreational trails, } \\
\text { natural setting, } \\
\text { privacy }\end{array}$ & $\begin{array}{l}\text { Keep price down for } \\
\text { property, natural } \\
\text { setting, low impact } \\
\text { land use }\end{array}$ & $\begin{array}{l}\text { Privacy, land value, } \\
\text { recreational trails }\end{array}$ \\
\hline Voting privileges & $\begin{array}{l}\text { Voting members vs. } \\
\text { non-voting members. } \\
\text { Voting members had } \\
\text { a say in the decisions } \\
\text { of the community. } \\
\text { Voting members }\end{array}$ & $\begin{array}{c}\text { Each lot is granted } \\
\text { one vote. Lot owners } \\
\text { have to be in } \\
\text { attendance of } \\
\text { meetings to vote }\end{array}$ & $\begin{array}{l}\text { Each lot is granted } \\
\text { one vote. Lot owners } \\
\text { have to be in } \\
\text { attendance of } \\
\text { meetings to vote }\end{array}$ \\
\hline
\end{tabular}


Community Issues

Financial value of common land to overall property of community

Personal value of common land to individual residents

Impact of restrictive covenants maintained equity ownership.

Phase III added with full time residence homes that did not fit with the recreational style homes in Phase I and II

Initially positive but over time reduced to neutral

Phase I and Phase II residents higher value as common land around lots, Phase III less value as majority of common lands not near lots

Highly controversial and seen to some to limit enjoyment of lots
Differing ideas of what to do with some of the common lands and how much to spend maintaining the common lands

Some lots have buildings and some do not creating almost a two tier of members

\section{Moderate increase}

Limited impact , enhancing value of property
Significant

Increased land value component of land value

Selects people of a similar interest will to accept restrictive covenants

\begin{tabular}{cccc}
\hline $\begin{array}{c}\text { Effectiveness of } \\
\text { restrictive covenants }\end{array}$ & $\begin{array}{c}\text { As time went on } \\
\text { observed less and less }\end{array}$ & Mostly observed & Mostly observed \\
\hline $\begin{array}{c}\text { Rational choice } \\
\text { design - cooperative } \\
\text { or competitive }\end{array}$ & Competitive & Cooperative & Cooperative \\
\hline
\end{tabular}

\section{Copyright Disclaimer}

Copyright for this article is retained by the author(s), with first publication rights granted to the journal.

This is an open-access article distributed under the terms and conditions of the Creative Commons Attribution license (http://creativecommons.org/licenses/by/3.0/). 